\title{
Understanding Nuances and Commonalities of Job Descriptions
}

\author{
Eka Raj Adhikari \\ Management Program, Training and Education Department, \\ Training Institute for Technical Instruction (TITI) \\ Sanothimi, Bhaktapur, Nepal \\ Email for correspondence: era@titi.org.np or ekarajadhikari@gmail.com
}

\begin{abstract}
This paper has explored how job descriptions are developed in today's organizations. As job descriptions are the foundations of jobs, they have to be prepared following certain guidelines. However, organizations follow different formats and put contents in those formats differently. This paper has searched for if there is a common ground in developing job descriptions. The paper is based on secondary sources of data. It compares and contrasts information from the available sources. The paper is an attempt to consolidate the pieces of knowledge that were already there. In doing so, it has also highlighted the gaps found in writing job descriptions which become remarkable avenues for further research. It concludes with the message that organizations can benefit if they follow the common practice of writing job descriptions discussed in the paper.
\end{abstract}

Key words: Job description, job analysis, performance expectations, performance appraisal

\section{Introduction}

'Right person in the right place' is heavily emphasized in today's world of management. We need certain tools and techniques to find out the right person. Finding out the right person with required educational qualification, experience and training is not enough. The incumbent has to be made clear regarding the duties and responsibilities $\mathrm{s} /$ he is expected to perform (Arthur, 2008). Again his/her performance has to be appraised in course of time and decisions need to be made about his/her performance. To do all these managerial activities, we need job descriptions.

There are various sorts of organizations. Some organizations are extremely hierarchical while others are flat. Some are private and some public. Some are specific to one particular locality and some are multinational. Whatever the nature of organization, they all have employees who perform. To make sure that their performance was on track and effective, they are provided with job descriptions. In this connection, Martin (2010) also states that the job description is to the job what the foundation is to the house.However, different organizations develop their own formats of job descriptions. In this context, this paper explores how to write effective job descriptions.

\section{Method}

This paper is based on secondary sources of data. The author reviewed the books, dissertations, journal articles.Some samples of job descriptions from some world renowned organizations were also reviewed. In reviewing the documents both electronic and hard 
copies were consulted. As Tylor (2011) mentions that review articles also provide the readers with practical insights, new thinking and new approaches to old problems, this paper has been prepared following that spirit.

\section{Concept of job description}

A job description is a written statement of the content of any particular job derived from job analysis (Cushway, 2003). Mader-Clark (2013, p. 3) defines it as "a clear and concise depiction of a job's duties and requirements". It is both a hiring blueprint and a performance management tool (Silverstein, 2007).

Here it is important not to get confused between job description and person specification/profile. Although the latter isalso a product of job analysis, it basically refers to a statement of the skills, knowledge and other attributes needed for effective performance in the job (Rudman, 2003).

\section{Importance of Job Description}

A job description is used for various purposes. First, it makes the incumbent clear about the duties and responsibilities $\mathrm{s} /$ he is expected to perform (Arthur, 2008). Employees who know what is expected of them can focus their energy on specific goals (Sandler $\&$ Keefe, 2004). Second, it communicates where an employee's position in the organization is and its relation to other positions in the company (Rudman, 2003). Next, it serves as a performance contract between management and employee. Likewise, the well-written, comprehensive job description sets a standard for performance (Silverstein, 2007). That is to say, this written document forms a solid base for measuring success and pay. Similarly, it is also helpful in performing job evaluation and job redesign (Cushway, 2003). Finally, it can be used in various HR processes like recruitment and selection, orientation, performance assessment, succession planning, coaching, training and compensation (Hampton, 1947; Firth, 1989; Martin, 2010; Royer, 2010).

\section{Components of Job Description}

There are variations in content and format of job descriptions between organizations (Firth, 1989). Despite having the disparities, an attempt has been made here to search for common elements of a job description.

According to Haynes (1990, pp. 66-67), the major elements of a job description are job identification, basic function, duties and responsibilities, delegation of authorities, working relationships, working conditions, and qualifications. The table presented below makes us further clear regarding the sequence and description of these elements:

Table 1

\section{Components of Job Description}

\begin{tabular}{ll}
\hline Components & Component Description \\
\hline Job identification & Department, location, salary grade or range, overtime status \\
Basic function & Job's basic purpose in brief and direct language \\
Duties and responsibilities & Principal duties and responsibilities in the order of their importance \\
Delegation of authorities & Financial and/or personnel authority if any \\
Working relationships & $\begin{array}{l}\text { Description of internal and external relationships like staff members, other } \\
\text { departments, customers, suppliers, government agencies, etc. }\end{array}$ \\
Working conditions & Work place, safety hazards, travel required, etc. \\
Qualifications & Required experience, training, and other qualifications \\
\hline
\end{tabular}


The components presented in Table 1 above are the common ones. These components appear in a sequential order in job descriptions. One example job description has been presented in Appendix B of this paper. However, these are not the only components of job descriptions. Other scholars have presented them in different terms. Some scholars have presented even greater number of components. Cushway (2003, pp. 6-9) talks about fifteen components of a good job description (see Appendix A).
Compared to the components given by Haynes (1990), the ones provided by Cushway (2003) are greater in number. Here it is important to note that all these components as provided by Cushway may not appear in all job descriptions. In this context, Brannick, Levine, and Morgeson (2007) categorize the different components of a job description into four major parts. These parts appear in almost all job descriptions. Their idea has been summarized in the following table:

Table 2

Major Parts of Job Description

\begin{tabular}{ll}
\hline Major Parts & Description of Parts \\
\hline Identifiers & Job title as well as the physical and functional locations of the job \\
Summary & $\begin{array}{l}\text { Description of the essence of the job; primary functions of the position } \\
\text { Duties and tasks }\end{array}$ \\
& $\begin{array}{l}\text { Details not found in the job summary; answers three questions - what, how, } \\
\text { and why }\end{array}$ \\
Other information & $\begin{array}{l}\text { Working conditions, required knowledge, skills, and abilities, or job evaluation } \\
\text { information }\end{array}$ \\
\hline
\end{tabular}

\section{Job Description Development Process}

It is important how job descriptions are developed. Organizations follow a standard process of developing job descriptions. According to Haynes (1990, pp. 65-66), the process of writing a job description consists of the following five stages:

\section{Information gathering}

In the first stage, necessary information about a job is collected, usually through job analysis. It is an act of gathering data about a specific job and what a person needs to do that job (Rudman, 2003). Sometimes, job descriptions are not developed through job analysis. In that case, managers and HR professionals list all the duties and responsibilities associated with a specific job and develop the job description (Royer, 2010).

\section{Drafting}

After collecting information, a draft is written. It is usually done by the person who collected the information. One important point is that the draft should follow the standard formatting desired by the organization (Haynes, 1990).

\section{Reviewing and approving}

Review and approval generally starts with the employee directly involved in the job. It then proceeds to the supervisor who is in charge of the job. Other managers and specialists may also contribute in reviewing the job descriptions.

\section{Finalizing}

Once the draft copy is approved, it is finalized by the authorized body of the organization. Now the job description is in the standard format and it can be provided to the concerned employee.

\section{Updating}

Jobs keep on changing in course of time. No job will 
stay the same for very long. Therefore, job descriptions must be kept up to date and relevant (Rudman, 2003).

\section{Discussion}

It has become clear that there is variation in contents and formats of job descriptions between organizations. Management experts have stressed on the point that there should not be different formats of job description in the same organization (Haynes, 1990). Now it has become a challenge to those organizations which do not have their own standard format of job description.

Cushway (2003) regards 'principal accountabilities or responsibilities' as the core of job description. According to Royer (2010), this section should answer the questions: what, how, and why. For example, one duty or task of a receptionist might be, "to answer phones using the switchboard in a timely fashion to ensure customers receive a prompt and courteous greeting." The what, in this example is "to answer phones ... in a timely fashion." The how refers to the equipment, in this case, the switchboard. The why refers to the goal of the task, in this case, the goal is for customers to "receive a prompt and courteous greeting." This piece of information is very important from performance appraisal point of view. Sandler and Keefe (2004) and Kirkpatrick (2006) also state that the performance appraisal is built upon the foundation of a wellcrafted job description. If the 'duties and responsibilities' section is presented in measurable terms, performance review becomes more objective. Therefore, utmost care must be provided in writing this section.

Employees may see the job description as defining the limits of their jobs and therefore refuse to do anything not specifically listed in the duties and responsibilities section. To circumvent this potential problem, the last item of the duties section on many job descriptions reads: "All other appropriate and reasonable duties that may be assigned" (Haynes, 1990). Perhaps outstanding performers are those who go beyond the duties and responsibilities that are given in the job description (DeNisi, 1996).

Job description and job specification are different things. Rudman (2003, p. 48) says, "Job descriptions and person profiles are different and should be kept separate." However, there are many scholars like Haynes (1990) who incorporate job specification in job description. In this connection, Cushway (2003) states:

While the knowledge, qualifications, skills and experience required to do the job are strictly part of a person specification, rather than a job description, it is useful to include them in one composite document which can then be used for a variety of purposes. (p. 9)

Some scholars like Haynes (1990) propose the idea of developing results areas and performance standards. However, they do not fully incorporate these things in the job description. The scholars suggest that such standards should supplement the job description in separate forms. On the other hand, there are other experts like Rudman (2003) who make the point that we can incorporate the results areas and performance standards in a single job description (see Appendix C).

Many interesting issues have emerged from the review. One issue is that who prepares job descriptions and how they are prepared in our organizational context. Another issue is the uses of job descriptions in our context.

\section{Conclusion}

A job description is a communication tool that makes the concerned employee clear about his/her duties and responsibilities. It is used in different HR processes like recruitment, selection, orientation, performance appraisal, job evaluation, job redesign, training, and compensation. Although it is not free from its limitations, it should be kept up to date, relevant and fresh. Experts have further stressed the point that employees are to be encouraged not to become rigid and be confined only to what has been there in job description. It is to be developed and 
used effectively so that it becomes a boon in organizational success. This review paper has brought different ideas together, sought a common thread of developing a job description, and opened avenues to interested bodies for further studies on itsdifferent aspects.

\section{References}

Arthur, D. (2008). The first-time manager's guide to performance appraisals. New York: American Management Association.

Brannick, M. T., Levine, E. L., \& Morgeson, F. P. (2007). Job and work analysis: Methods, research, and applications for human resource management ( $2^{\text {nd }}$ ed.). Los Angeles: SAGE Publications.

Cushway, B. (2003). Handbook of model job descriptions. London: Kogan Page.

DeNisi, A. S. (1996). A cognitive approach to performance appraisal: A program of research. London: Rutledge.

Falcone, P. \& Sachs, R. (2007). Productive performance appraisals ( $2^{\text {nd }}$ ed.). New York: American Management Association.

Firth, R. (1989). Write a job description. BMJ: British Medical Journal, 298(6683), 1306-1307. Retrieved on 12-05-2015 from www.jstor.org/ stable/29703977

Hampton, P. J. (1947). An introduction to job description. The American Journal of Nursing, 47(6), 411-413. Retrieved on 12-05-2015 from www.jstor.org/stable/3457145
Haynes, M. E. (1990). Managing performance: A comprehensive guide to effective supervision $\left(2^{\text {nd }}\right.$ ed.). Menlo Park, California: Crisp Publications, Inc.

Kirkpatrick, D. L. (2006). Improving employee performance through appraisal and coaching $\left(2^{\text {nd }}\right.$ ed.). New York: American Management Association.

Mader-Clark, M. (2013). The job description handbook ( $3^{\text {rd }}$ ed.). Berkeley: Nolo.

Martin, C. (2010). Perfect phrases for writing job descriptions. New York: McGraw-Hill.

Royer, K. P. (2010). Job descriptions and job analyses in practice: How research and application differ (Doctoral dissertation, College of Liberal Arts and Social Sciences, DePaul University, Chicago). Retrieved on May 21, 2015 from http://via.library. depaul.edu/etd/50

Rudman, R. (2003). Performance planning and review: Making employee appraisals work $\left(2^{\text {nd }}\right.$ ed.). Crows Nest, NSW: ALLEN \& UNWIN.

Sandler, C. \& Keefe, J. (2004). Performance appraisal phrase book: The best words, phrases and techniques for performance reviews. Avon, Massachusetts: Adams Media.

Silverstein, B. (2007). Evaluating performance: How to appraise, promote and fire. New York: HarperCollins.

Tylor, R. B. (2011). Medical writing: A guide for clinicians, educators and researchers ( $2^{\text {nd }} \mathrm{ed}$.). Oregon: Springer. 


\section{AppendixA}

Components of Job Description Given by Cushway (2003, pp. 6-9)

\begin{tabular}{|c|c|}
\hline Components & Component Description \\
\hline Job identification & Job title, department or section, employee or job number \\
\hline Reporting line & Title of the job to which the employee directly reports \\
\hline Organization structure & Skeleton of the organization (details attached with JD) \\
\hline Main purpose of the job & Main purpose distinguishes this job from other jobs \\
\hline Principal accountabilities or responsibilities & $\begin{array}{l}\text { Identification of key areas of responsibilities as well as } \\
\text { the end results and description of how these end results } \\
\text { are achieved; core part of JD }\end{array}$ \\
\hline Performance measures or standards & $\begin{array}{l}\text { Output expected from the job and the standards to which } \\
\text { it is to be performed }\end{array}$ \\
\hline Constraints & Limits of authority and decision making \\
\hline Statistics & $\begin{array}{l}\text { Details of any budget, equipment, or other resources the } \\
\text { job holder is responsible for }\end{array}$ \\
\hline Nature and scope & $\begin{array}{l}\text { Context of the job in the organization; how the job relates } \\
\text { to other jobs in the organization; where work comes from } \\
\text { and where it goes to; nature of problems }\end{array}$ \\
\hline Contacts & Nature and range of contacts of the job \\
\hline Working conditions & Nature of the working environment \\
\hline Knowledge, skills and experience & $\begin{array}{l}\text { Knowledge, qualifications, skills and experience required } \\
\text { to do the job }\end{array}$ \\
\hline Competencies & $\begin{array}{l}\text { Personal characteristics and qualities of individuals that } \\
\text { enable them to perform the job effectively }\end{array}$ \\
\hline Other information & Miscellaneous or additional information if any \\
\hline Signature and date & $\begin{array}{l}\text { Signatures of both employee and manager to indicate that } \\
\text { it is an agreed document }\end{array}$ \\
\hline
\end{tabular}




\section{Appendix B}

Example Job Description from Haynes (1990, pp. 67-70)

\section{Instructor: Management and Supervisory Skills}

Department: Employee Relations

Date: July 1, 2014

Division: Management Development

Salary Grade: 10-12

Location: Head Office

\section{Basic Functions}

Instructors in management and supervisory skills design and present training seminars and workshops to increase the effectiveness of the company's managers and supervisors. They are expected to utilize effective instructional techniques in order to maximize the learning experience. Program designs vary in length from two hours to a full week or more depending upon the nature of material to be covered.

\section{Duties and Responsibilities}

1. Present training material in a classroom setting in lecture/discussion format supplemented with appropriate exercises and audio-visual equipment.

2. Design training programs to accomplish learning objectives.

3. Select and/or design appropriate training materials and coordinate their purchase or reproduction.

4. Arrange for, or advise host locations on, facilities required to accommodate class size and program design.

5. Coordinate program attendance, or advise host locations, to verify appropriate match between target audiences and participants.

6. Evaluate programs presented to ensure attainment of learning objectives. Modify program design as required.

7. Counsel participants' supervisor on appropriate ways to reinforce learning in the workplace.

8. Stay abreast of developments in the profession and needs within the organization and propose new programs as appropriate.

9. Prepare and submit annual budget proposals for assigned program areas.

10. Monitor expenses, by program, to stay within approved budget.

11. Advice field level training personnel on program design, instructional techniques, and evaluation techniques as required.

12. Carry out special projects and all other appropriate and reasonable duties that may be assigned from time to time.

\section{III.Delegation of Authorities}

1. Personnel Authority: This position has no delegated personnel authority.

2. Financial Authority: This position has approval authority for the purchase of goods and services up to $\$ 5,000$ per purchase against approved budget. 


\section{Working Relationships}

\section{Departmental Staff}

Must negotiate with other staff members to share the services of administrative support and secretarial staff over whom the employee has no supervisory authority.

\section{Service Departments}

Must work effectively with purchasing, graphics, printing, and correspondence services in arranging for the procurement or production of training materials.

\section{Client Departments}

Must provide for the balance of participation in program areas from various client departments served.

\section{Suppliers}

Must manage the procurement and delivery of meeting facilities and support services from outside suppliers.

\section{Working Conditions}

This job is performed in both an office and classroom environment. Substantial travel is required with about 75 percent of the work being carried out away from headquarters.

\section{VI.Qualifications}

1. Must be able to work effectively with others over whom he or she has no organizational authority.

2. Must be familiar with, and supporting of, current approaches to optimizing the utilization of resources.

3. Must be familiar with the company's management philosophy and organizational structure.

4. Must be familiar with training program design and the utilization of audio-visual techniques.

5. Must be an effective public speaker.

6. Must be able to perform successfully under minimum supervision.

7. Must be sufficiently flexible and resourceful to cope with the inherent uncertainties of the profession.

8. Must have experienced sufficient organizational success to establish credibility with participants. 


\section{Appendix C}

Example Job Description from Rudman (2003, pp. 50-51)

\begin{tabular}{|c|c|c|}
\hline Position & \multicolumn{2}{|l|}{ Manager, Warehouse and Distribution } \\
\hline Department & \multicolumn{2}{|l|}{ Production } \\
\hline Date Prepared & \multicolumn{2}{|l|}{ June 2003} \\
\hline Manager's Signature & \multicolumn{2}{|l|}{$\ldots \ldots \ldots \ldots \ldots \ldots \ldots \ldots$} \\
\hline Job Holder's Signature & \multicolumn{2}{|l|}{$\ldots \ldots \ldots \ldots \ldots \ldots \ldots \ldots \ldots$} \\
\hline \multicolumn{3}{|c|}{$\begin{array}{l}\text { Position Purpose } \\
\text { Provides leadership and guidance to warehouse and distribution team members to ensure that customers } \\
\text { receive the products they order in good condition and on time. }\end{array}$} \\
\hline Reports to & \multicolumn{2}{|c|}{ Production Manager } \\
\hline Responsible for & \multicolumn{2}{|c|}{ Warehouse assistants (4), Van Driver, Administrative Officer } \\
\hline Functional Relationships & \multicolumn{2}{|c|}{$\begin{array}{l}\text { Sales and Marketing Manager, Accounts Team Leader, Sales Executives, } \\
\text { HR Manager, Team Leader, Final Assembly, Health and Safety Advisor }\end{array}$} \\
\hline Authorities & \multicolumn{2}{|c|}{$\begin{array}{l}\text { Financial } \\
\text { Approves expenditure within agreed operating budget } \\
\text { Contracts } \\
\text { Recommends courier and other transport contracts for approval of } \\
\text { Production Manager } \\
\text { Staffing } \\
\text { Makes recommendations for approval of Production Manager }\end{array}$} \\
\hline Key Results Areas & Performance Standards & Reporting Information \\
\hline $\begin{array}{l}\text { Warehouse and distribution staff } \\
\text { have knowledge, skills, } \\
\text { leadership and direction they } \\
\text { need for satisfactory } \\
\text { performance }\end{array}$ & $\begin{array}{l}\text { Job descriptions, performance } \\
\text { plans and reviews, and } \\
\text { development plans are in place for } \\
\text { all employees } \\
\text { Employees are aware of workplace } \\
\text { hazards and trained in safe working } \\
\text { practices, handling hazardous } \\
\text { materials, safe use of equipment } \\
\text { and processes, and proper use of } \\
\text { safety devices }\end{array}$ & $\begin{array}{l}\text { Six-monthly activity report to } \\
\text { production manager } \\
\text { Performance plans and reviews are } \\
\text { passed to Production Manager for } \\
\text { information and review } \\
\text { Six-monthly report to Production } \\
\text { Manager, with supporting audit by } \\
\text { Health and Safety Advisor }\end{array}$ \\
\hline
\end{tabular}




\begin{tabular}{|c|c|c|}
\hline $\begin{array}{l}\text { Customer satisfaction is } \\
\text { enhanced by accurate and on- } \\
\text { time delivery of orders }\end{array}$ & 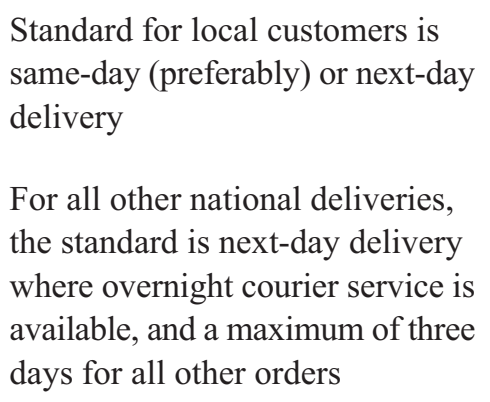 & $\begin{array}{l}\text { Immediate report of stock } \\
\text { shortages to Production Manager } \\
\text { following comparison of sales } \\
\text { orders and inventory control } \\
\text { information } \\
\text { Immediate report of late deliveries } \\
\text { to Sales and Marketing Manager } \\
\text { and Production Manager }\end{array}$ \\
\hline $\begin{array}{l}\text { Warehouse housekeeping } \\
\text { contributes to efficient } \\
\text { operations and maintenance of } \\
\text { pleasant and safe workplace; } \\
\text { careful handling and storage } \\
\text { ensure stock is clean and } \\
\text { undamaged }\end{array}$ & $\begin{array}{l}\text { Housekeeping and handling meet } \\
\text { company requirements and } \\
\text { standards } \\
\text { No orders rejected by customers } \\
\text { because of appearance or damage } \\
\text { No more than } 1 \% \\
\text { ofwarehousestock is returned to } \\
\text { factory forrework because of dirt } \\
\text { ordamage }\end{array}$ & $\begin{array}{l}\text { Monthly inspection by Production } \\
\text { Manager and Health and Safety } \\
\text { Adviser } \\
\text { Immediate report of complaints or } \\
\text { rejects to Sales and Marketing } \\
\text { Manager and Production Manager } \\
\text { Three-monthly report to Production } \\
\text { Manager on returns }\end{array}$ \\
\hline $\begin{array}{l}\text { Warehouse and distribution } \\
\text { operating plans and budgets are } \\
\text { prepared in line with company } \\
\text { requirements and objectives and } \\
\text { implemented following } \\
\text { approval }\end{array}$ & $\begin{array}{l}\text { Draft plans and budgets are } \\
\text { prepared in the required format } \\
\text { and time frame } \\
\text { Warehouse and distribution costs } \\
\text { are kept within agreed budget } \\
\text { levels } \\
\text { Additional expenditure requires } \\
\text { prior approval of Production } \\
\text { Manager }\end{array}$ & $\begin{array}{l}\text { Monthly report of budget/actual } \\
\text { expenditure to Production Manager }\end{array}$ \\
\hline
\end{tabular}

